\title{
Soft Capsule Dosage Form
}

National Cancer Institute

\section{Source}

National Cancer Institute. Soft Capsule Dosage Form. NCI Thesaurus. Code C64909.

A capsule composed of active and/or inert ing redient(s) covered with a soft outer shell, which is usually prepared from gelatin. 